\title{
Overin Sklerozan Stromal Tümörü Sclerosing Stromal Tumor of the Ovary
}

\author{
${ }^{1}$ Didem Turcan, ${ }^{1}$ Funda Canaz, ${ }^{1}$ Evrim Yılmaz, ${ }^{1}$ Sare Kabukçuoğlu, ${ }^{2}$ Melih \\ Velipaşaoğlu \\ ${ }^{1}$ Eskişehir Osmangazi Üniversitesi Tıp Fakültesi, Tıbbi Patoloji Anabilim Dalı, Eskişehir,Türkiye \\ ${ }^{2}$ Eskişehir Osmangazi Üniversitesi Tıp Fakültesi, Kadın Hastalıkları ve Doğum Anabilim Dalı, Eskişehir, \\ Türkiye
}

Özet: Overin sklerozan stromal tümörü seks kord stromal tümörler kategorisinde yer alır ve bu gruptaki tümörlerin \%2-6'sını oluşturur. Bu tümör, histolojik olarak hyalinize veya ödemli stromayla ayrılan hücreden zengin lobül benzeri yapılardan oluşur. Bu alanlar, iğsi hücreler ve oval-yuvarlak hücreler olmak üzere iki farklı hücre tipi içerir. Burada sklerozan stromal tümör tanısı almış üç olgu sunulmuştur. Amacımız overin sklerozan stromal tümörünü klinikopatolojik özellikleri ile sunmak ve ayırıcı tanııı son literatür bilgilerini de gözden geçirerek tartışmaktır.

Anahtar Kelimeler: over, over tümörleri, seks kord-stromal tümör, immünohistokimya

Turcan D. Canaz F. Yılmaz E. Kabukçuoğlu S. Velipaşaoğlu M. (2017). Overin sklerozan stromal tümörü, Osmangazi Tip Dergisi 39(2): 75-79 Doi: $10.20515 /$ otd.330022

\begin{abstract}
The sclerosing stromal tumor (SST) of the ovary belongs to sex cord-stromal tumors category and is accounted for 2-6\% of this group. Histologically, this tumor consists of cellular pseudolobules that were seperated by hyalinized or oedematous stroma. These areas include two different cell types; spindle shaped and round to oval cells. Three cases diagnosed as sclerosing stromal tumor were presented in this article. Aim of this article is to present clinicopathologic features of SST and to discuss the differential diagnosis by reviewing the recent literature.
\end{abstract}

Keywords: ovary, ovary neoplasms, sex cord-stromal tumor, immunohistochemistry 


\section{Giriş}

Overin sklerozan stromal tümörü seks kord stromal tümörler kategorisinde yer alan, nadir görülen bir neoplazmdır (1). Bu tümör ilk olarak 1973 yılında Chalvardjian ve Scully (2) tarafindan tanımlanmıştır. Olguların \%80'i ikinci ve üçüncü dekatta görülür (1). Sklerozan stromal tümörler genellikle hormonal olarak inaktiftir, ancak gebelik, androjenik semptomlar ve endometrial karsinomla ilişkili olgular da bildirilmiştir (3). Burada sklerozan stromal tümör tanısı almış üç olgunun histopatolojik ve immünohistokimyasal özellikleri literatür bilgileri eşliğinde sunulmuştur.

\section{Olgu-1}

30 yaşında kadın hasta karın ağrısı şikayetiyle başvurdu. Yapılan ultrasonografik incelemesinde sağ adneksiyal alanda kitle izlendi. Tümör belirteçlerini de içeren laboratuvar testleri normaldi. Hastaya sağ unilateral ooforektomi yapıldı. Makroskopik incelemede $5.5 \times 4 \times 2.5 \mathrm{~cm}$ boyutlarında, dış yüzeyi düzgün, kapsüllü tümöral lezyonun kesit yüzeyinde $1 \mathrm{~cm}$ çapında kistik alan izlendi. Diğer alanlarda tümör gri beyaz, solid, ödematöz görünümdeydi. Mikroskopik incelemede hücresel alanların ödematöz ve kollajenize hiposellüler alanlarla ayrıldı̆̆ı lobül benzeri yapılar ve belirgin vaskülarite artışı görüldü (Resim 1).

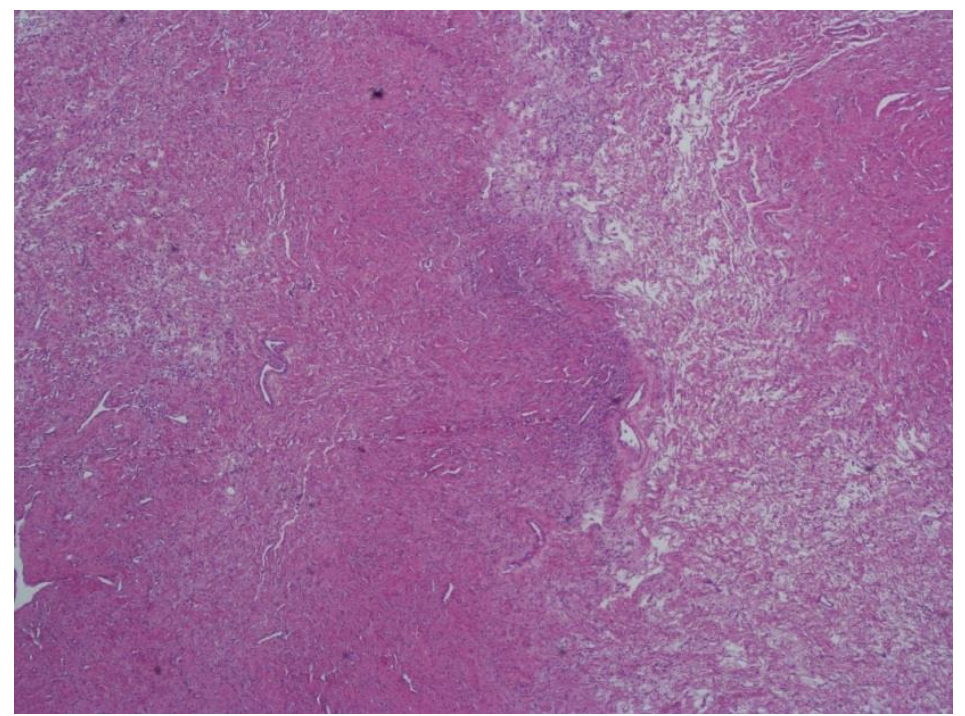

Resim 1. Lobül benzeri patern oluşturan sellüler ve hiposellüler alanlar (H\&E, x40)

Tümör iğsi hücreler ve yuvarlak vakuolize hücrelerden oluşan heterojen görünümdeydi (Resim 2).

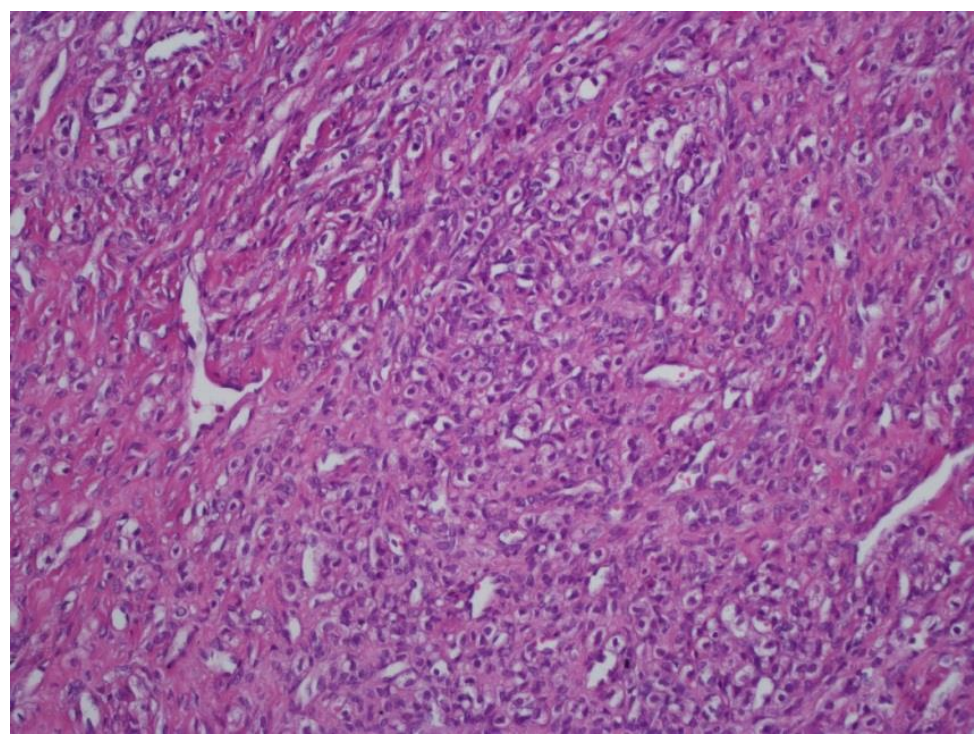

Resim 2. Yuvarlak nükleuslu, vakuolize sitoplazmalı teka benzeri hücreler (H\&E, x200) 
Sitolojik atipi ve mitoz izlenmedi. vakuolize sitoplazmalı hücreler inhibin İmmünohistokimyasal çalışmalarda fibroblast (Resim 3) ve kalretinin pozitifti. benzeri hücreler aktin, teka hücresi benzeri

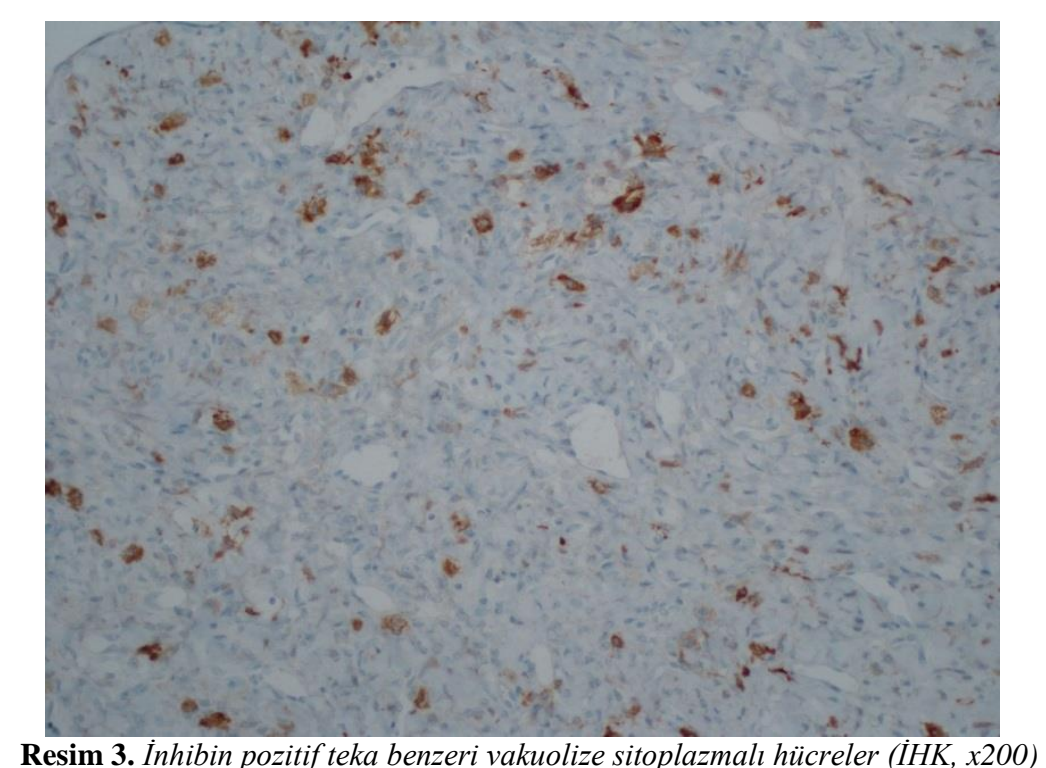

Vimentin ile tümöral hücrelerde yaygın pozitiflik mevcuttu. Progesteron reseptör ile kuvvetli (Resim 4), östrojen reseptör ile zayıf boyanma izlendi. Tümöral hücrelerde keratin,
CD34 ve müsin negatifti. Patoloji sonucu overin sklerozan stromal tümörü olarak raporlandi.

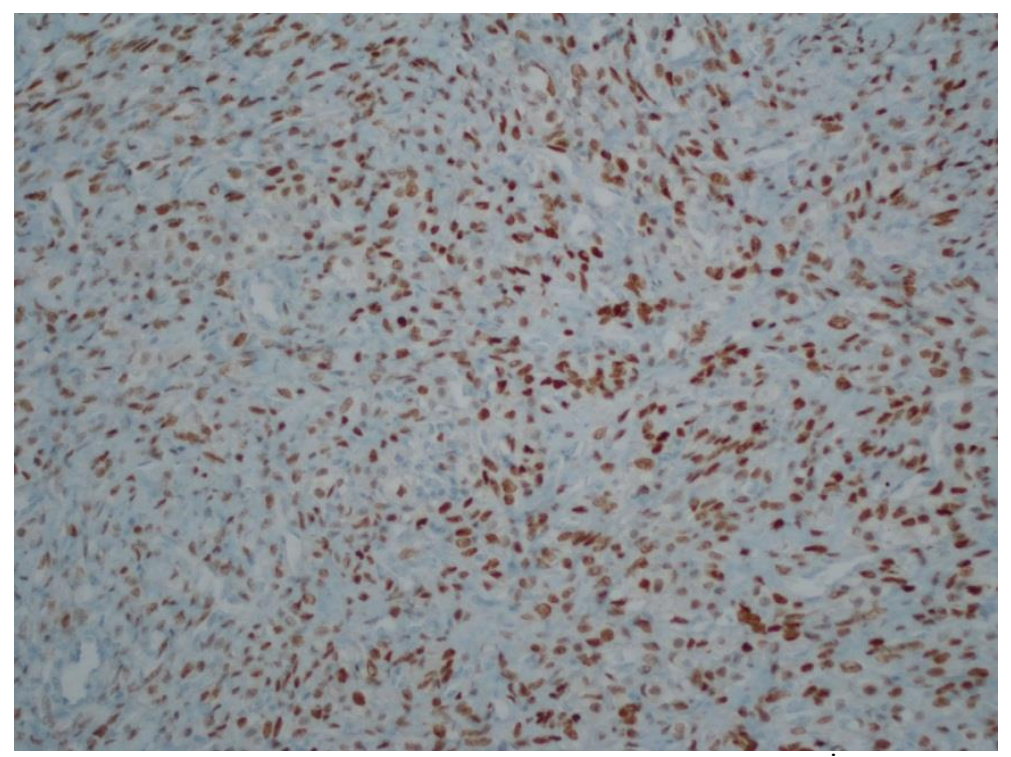

Resim 4. Progesteron reseptör ile kuvvetli pozitif boyanma (IHK, x200)

\section{Olgu-2}

18 yaşında kadın hasta karın ağrısı ve menoraji şikayetiyle başvurdu. Yapılan ultrasonografik incelemesinde sol overde, $8 \times 7 \times 6 \mathrm{~cm}$ boyutlarında, anekoik kistik alanların izlendiği, kalın septaları olan semisolid kitle mevcuttu. Laboratuvar testlerinde CA-125 55.3 U/ml (Referans aralığı: 0-35 U/ml) saptandı. Hastaya sol unilateral salpingo-ooforektomi yapıldı. İntraoperatif frozen değerlendirmede malignite izlenmedi. Makroskopik incelemede $8 \times 6 \times 4 \mathrm{~cm}$ boyutlarında izlenen tümörün kesit yüzeyi gri beyaz, ödematöz, yer yer kistik görünümdeydi. Histopatolojik olarak tümör küçük büyütmede lobül benzeri görünüm oluşturan hipersellüler ve hiposellüler 
alanlardan oluşmaktayd1. Hücreden zengin alanlarda iğsi fibroblast benzeri ve yuvarlak luteinize hücrelerin bulunduğu iki hücre tipi izlendi. Çok sayıda küçük-orta boyutlu, ince duvarlı, dallanmalar gösteren damarlar görüldü. İmmünohistokimyasal çalışmalarda vimentin ile yaygın pozitiflik izlendi. Aktin iğsi fibroblast benzeri hücrelerde, inhibin ve kalretinin yuvarlak luteinize hücrelerde pozitifti. Progesteron reseptör ile daha belirgin olmak üzere progesteron reseptör ve östrojen reseptör pozitifti. Ayırıcı tanı için uygulanan CD34, keratin immünohistokimyasal boyaları ve müsin histokimyasal boyas1 ile tümöral hücrelerde pozitiflik izlenmedi. Bu bulgularla hastaya overin sklerozan stromal tümörü tanıs1 verildi.

\section{Olgu-3}

19 yaşında kadın hasta karın ağrısı şikayetiyle başvurdu. Yapılan ultrasonografik incelemesinde uterus önünde, tüm pelvisi dolduran, abdomene uzanan 146x128x47 mm boyutlarında kitle izlendi. Tümör belirteçlerini de içeren laboratuvar testleri normaldi. Hastaya sağ unilateral salpingo-ooforektomi yapıldı. İntraoperatif frozen değerlendirmede malignite görülmedi. Makroskopik incelemede $16 \times 14 \times 7 \mathrm{~cm}$ boyutlarında dış yüzü düzgün, kapsüllü tümöral lezyon izlendi. Materyal açıldığında içinden serohemorajik sıvı drene oldu. Kesit yüzeyi yer yer kistik görünümdeydi. Mikroskopik olarak tümör hücrelerinin düzensiz dağılımı hiposellüler alanlarla ayrılmış hipersellüler psödolobüller oluşturmaktaydı. Sellüler alanlarda aktin pozitif iğsi hücreler ile inhibin ve kalretinin pozitif vakuolize sitoplazmalı teka hücresi benzeri hücreler izlendi. Hemanjioperistomatöz patern gösteren belirgin damar ağı görüldü. İmmünohistokimyasal çalışmalarda progesteron reseptör ve östrojen reseptör pozitif, keratin, CD34 ve müsin negatifti. Histopatolojik tanı overin sklerozan stromal tümörü olarak verildi.

\section{Tartışma}

Sklerozan stromal tümör overin seks kord stromal tümörlerinin benign bir subtipidir. Seks kord stromal tümörler over neoplazilerinin yaklaşık \%8'ini oluşturur ve sklerozan stromal tümörlerin bu grup içindeki oranı \%5'ten daha azdır (4). Bu tümör genellikle ikinci ve üçüncü dekatta görülür. Ancak literatürde postmenopozal dönemde ve çocukluk çağında bildirilmiş olgular da mevcuttur (5-7). Menstruel düzensizlikler ve pelvik ağrı en sık semptomlardır (3). Küçük tümörler yanı sıra $10 \mathrm{~kg}$ ağırlığa ulaşan tümör de bildirilmiştir. Yükselmiş CA-125 değerleri ve/veya asit gözlenen olgular da vardır (6-8). Burada sunulan olgular da 2. ve 3. dekatta tan1 almış olup, hastaların ikisi karın ağrısı, biri menoraji şikayetiyle başvurmuştur. Olgulardan birinde hafif düzeyde CA-125 yüksekliği saptanmıştır.

Sklerozan stromal tümör karakteristik histopatolojik özellikleri ile overin diğer stromal tümörlerinden ayrilır. $\mathrm{Bu}$ tümörler hyalinize veya ödemli stromayla ayrılan hücreden zengin lobül benzeri yapılardan oluşur ve hemanjioperistomatöz patern gösteren belirgin damar ağı içerir. Lobül benzeri alanlarda; kollajen üreten iğsi hücreler ve lipid içeren yuvarlak oval hücreler olmak üzere iki hücre tipi izlenir (9). Bizim olgularımızda histopatolojik özellikler literatür ile uyumlu olup, bir olguda hiposellüler alanlarda ödem ve hyalinizasyon daha belirgin olarak izlenmiştir.

İki hücre tipinden oluşan heterojen popülasyon sklerozan stromal tümörü daha homojen olan tekoma ve fibromalardan ayırt etmede yardımc1 bir bulgudur. Ayrica tekoma ve fibromalar genellikle beşinci veya altınc1 dekatta görülür. Belirgin vaskülarite sebebiyle vasküler tümörler de ayırıcı tanıda göz önünde bulundurulmalıdır. İnhibin, düz kas aktin, vimentin pozitifliği ve hücresel alanlarda vasküler immünohistokimyasal belirleyicilerin negatifliği sklerozan stromal tümörü destekleyen özelliklerdir (4, 9). İnhibin sklerozan stromal tümörlerin tanısında kullanılan sensitif bir belirleyicidir, ancak bazı olgularda negatif olduğu da bildirilmiştir. Mezotelyal bir belirleyici olan kalretinin seks kord stromal tümörlerin tanısinda daha sensitif ancak daha az spesifik bir belirleyicidir ve özellikle inhibin negatif olgularda tanıya yardımeı olarak kullanılabilir (10).

Nadiren taşlı yüzük hücresi görünümündeki vakuolize hücreler Krukenberg tümörü ile ayırıc1 tanıda zorluğa sebep olabilir. Krukenberg tümörü genellikle bilateraldir ve daha ileri yaşlarda görülür. Krukenberg tümörü sklerozan stromal tümörde görülen psödolobüler paterni göstermez ve taşlı yüzük hücreleri müsin içerir (4). Sklerozan stromal tümördeki vakuolize hücreler ise inaktif veya 
zayıf aktivite gösteren ve yağ içeren luteinize hücrelerdir (1). İmmünohistokimyasal olarak keratin ve EMA negatifliğinin gösterilmesi de Krukenberg tümör tanısının dişlanmasına yardımcıdır (1, 3). Burada sunulan olgular ikinci ve üçüncü dekatta tanı almış olup, inhibin, kalretinin, düz kas aktin ve vimentin pozitifliği literatür ile uyumludur. CD34 immünohistokimyasal belirleyicisinin tümöral hücrelerde negatif olması ile vasküler tümörler dışlanmıştır. Olgulardan birinde daha az sayıda olmak üzere her üç olguda da taşlı yüzük görünümünde vakuolize hücreler saptanmış, klinik özellikleri, karakteristik mikroskobik görünümü, keratin ve müsin negatifliği ile de Krukenberg tümör olasılığı dişlanmıştır.

Kostopoulou ve ark. (11) sklerozan stromal tümörlerde immünohistokimyasal olarak östrojen reseptör alfa ve beta ekspresyonunu değerlendirmiş, östrojen beta ile östrojen alfa'ya oranla daha fazla sayıda hücrede boyanma izlemişlerdir. Kaygusuz ve ark. (3) yaptıları çalışmaya dahil ettikleri olguların tümünde progesteron reseptör ile fokal boyanma izlerken, östrojen reseptörün hiçbir olguda boyanmadığını bildirmişlerdir. Zekioğlu ve ark. (1) ondört sklerozan stromal tümör olgusundan ikisinde progesteron reseptör ile boyanma izlemiştir. Östrojen reseptörle boyanma saptamamıştır. Bizim olgularımızda progesteron reseptörü ile daha belirgin olmak üzere her iki belirteçle de pozitif boyanma görülmüştür. $\mathrm{Bu}$ bulgu tümörlerin fonksiyonel stromaya sahip olduğunu düşündürmüştür.

\section{Sonuç}

Overin sklerozan stromal tümörünü görüntüleme çalışmalarıyla tanımlamak ve malign tümörlerden ayırt etmek zordur. Kaynaklarda ultrasonografi, bilgisayarlı tomografi ve manyetik rezonans görüntüleme yöntemlerinin etkinliğini karşılaştıran çalışmaların sonuçları da tartışmalıdır (12). Nadir görülen bir neoplazi olması sebebiyle de, preoperatif olarak akla gelmesi her zaman mümkün olmayabilir. Özellikle genç hastalarda benign bir lezyon olduğu ve enükleasyon ya da unilateral ooforektomiyle tedavi edilebileceği için sklerozan stromal tümör olasılığı unutulmamalıdır.

\section{KAYNAKLAR}

1. Zekioglu, O., Ozdemir, N., Terek, C., Ozsaran, A., \& Dikmen, Y. (2010). Clinicopathological and immunohistochemical analysis of sclerosing stromal tumours of the ovary. Archives of gynecology and obstetrics, 282(6), 671-676.

2. Chalvardjian, A., \& Scully, R. E. (1973). Sclerosing stromal tumors of the ovary. Cancer, 31(3), 664-670.

3. Kaygusuz, E. I., Cesur, S., Cetiner, H., Yavuz, H., \& Koc, N. (2013). Sclerosing stromal tumour in young women: clinicopathologic and immunohistochemical spectrum. $J$ Clin Diagn Res, 7(9), 1932-1935.

4. Khanna, M., Khanna, A., \& Manjari, M. (2012). Sclerosing stromal tumor of ovary: a case report. Case reports in pathology, 2012.

5. Kim, T. H., Lee, H. H., Hong, J. A., Park, J., Jeon, D. S., Lee, A., \& Koh, E. S. (2014). Sclerosing stromal tumor in an elderly postmenopausal woman. Journal of Menopausal Medicine, 20(2), 80-83.

6. Youm, H. S., Cha, D. S., Han, K. H., Park, E. Y., Hyon, N. N., \& Chong, Y. (2008). A case of huge sclerosing stromal tumor of the ovary weighing $10 \mathrm{~kg}$ in a 71-year-old postmenopausal woman. Journal of gynecologic oncology, 19(4), 270-274.

7. Chaurasia, J., Afroz, N., Maheshwari, V., \& Naim, M. (2014). Sclerosing stromal tumor of the ovary presenting as precocious puberty: Unusual presentation of the rare neoplasm. International Journal of Medicine and Public Health, 4(3), 307-307.

8. Peng, H. H., Chang, T. C., \& Hsueh, S. (2003). Sclerosing stromal tumor of ovary. Chang Gung medical journal,26(6), 444-448.

9. Akbulut, M., Colakoglu, N., Soysal, M. E., \& Duzcan, S. E. (2004). Sclerosing stromal tumor of the ovary: report of a case and review of the literature. Aegean Pathol J, 1, 84-89.

10. Movahedi-Lankarani, S., \& Kurman, R. J. (2002). Calretinin, a more sensitive but less specific marker than $\alpha$-inhibin for ovarian sex cord-stromal neoplasms: an immunohistochemical study of 215 cases. The American journal of surgical pathology, 26(11), 1477-1483.

11. Kostopoulou, E., Moulla, A., Giakoustidis, D., \& Leontsini, M. (2003). Sclerosing stromal tumors of the ovary: a clinicopathologic, immunohistochemical and cytogenetic analysis of three cases. European journal of gynaecological oncology, 25(2), 257-260.

12. Dilbaz, B., Tasc1, Y., Ulular, Y., Demir, Ö. F., \& Göktolga, Ü. (2011). Sclerosing Stromal Tumor of the ovary. J Turk Soc Obstet Gynecol, 8, 286-8. 